\title{
Epidemiologic investigation of the re-emergence of infectious salmon anemia virus in Chile
}

\author{
Fernando O. Mardones*, Andrés M. Perez, Tim E. Carpenter \\ Center for Animal Disease Modeling and Surveillance (CADMS), Department of Medicine and Epidemiology, \\ School of Veterinary Medicine, University of California, Davis, California 95616, USA
}

\begin{abstract}
Reports from surveillance activities were analyzed to determine the epidemiology of the re-emergence of infectious salmon anemia virus (ISAV) in Atlantic salmon farms in Chile. The epidemic and spatial and spatiotemporal patterns were described, taking into account commercial compartmentalization of the farms. During the $64 \mathrm{wk}$ study period, 76 ISAV-infected salmon farms, representing 17 companies, were reported in $65 \%$ of the management geographic zones of the 10 th region in southern Chile. Approximately $20 \%$ of the farms at risk became infected, with the incidence rate increasing slightly over time. Results from epidemic analyses and observed spatial and spatiotemporal patterns suggested an initial dispersal and subsequent clustering of cases around the index case (IC) in a propagated epidemic mode. Results suggested that delayed depopulation may have been a key factor in the spread and persistence of ISAV. Clustering of cases supported the assumption that passive transmission in seawater from ISAV-infected farms (proximity) is a critical factor in controlling disease. The re-emergence of ISAV in Chile has resulted in one of the largest ISAV epidemics reported in the world and this study generates new hypotheses and provides useful information for spatial disease control planning in salmon farming areas.
\end{abstract}

KEY WORDS: Infectious salmon anemia · ISAV $\cdot$ Chile $\cdot$ Atlantic salmon $\cdot$ Salmo salar $\cdot$ Spatial epidemiology

\section{INTRODUCTION}

Infectious salmon anemia (ISA) is a highly contagious disease caused by an orthomyxovirus referred to as ISA virus (ISAV) (Falk et al. 1997). ISA affects predominantly farmed Atlantic salmon Salmo salar during the pre-market grow-out phase in a marine environment. Due to its infectious nature and associated economic impact, ISA is listed as a notifiable disease by the World Organization for Animal Health (OIE). ISAV was first isolated in Norway in 1984 (Thorud \& Djupvik 1988). Subsequently, ISAV has spread throughout Norway and remains endemic along most of the country's shoreline (Lyngstad et al. 2008). The first ISA outbreak affecting farmed salmon outside Norway was reported in 1996 in New Brunswick, Canada, however, ISAV infection in this industry had been suspected since 1994 (Mullins et al. 1998, Lovely et al. 1999) and the last virulent strain of ISAV was detected in this area by active surveillance in June 2007 (M. Beattie pers. comm.). Outbreaks have been reported in Scotland in 1998 (Rodger et al. 1998), on Faroe Island in 2000 (Lyngøy 2003) and in the USA in 2001 (T. Robinson pers. comm.). ISAV was isolated from diseased farmed Coho salmon Oncorhynchus kisutch in Chile in 1999 (Kibenge et al. 2001), and in apparently healthy farmed rainbow trout Oncorhynchus mykiss in Ireland in 2002 (Anonymous 2002). As of today, eradication following an epidemic has only been achieved in Scotland (Stagg et al. 2001).

The pattern of previous ISAV outbreaks in Norway, Canada and the USA suggests a strong spatial component in the virus's dispersal. Techniques for the detection of spatial and spatiotemporal clusters described elsewhere (Carpenter 2001) have been commonly applied as a useful tool in other highly infectious disease epidemics, such as foot-and-mouth disease (FMD) or avian influenza (AI) (Perez et al. 2004, Ward et al. 2008). 
ISAV is transmitted mainly horizontally by passive movement of infected sea water, with higher risk the closer a susceptible farm is to an infected processing (harvest) plant or farm (<5 km) (Vågsholm et al. 1994, Jarp \& Karlsen 1997, McClure et al. 2005). Several environmental and husbandry-related factors and practices have been associated with ISAV transmission, both within and between farms (Vågsholm et al. 1994, Jarp \& Karlsen 1997, Murray et al. 2002, Munro et al. 2003, Gustafson et al. 2005, Hammell \& Dohoo 2005a, McClure et al. 2005, Gustafson et al. 2007). For example, short nets $(<9 \mathrm{~m})$, a deep column of water underneath the net $(>3 \mathrm{~m})$, and intense contact with wild fish have been suggested as environmental risk factors for the disease. In addition, harvesting methods, shared personnel (divers), and quality of stocked smolts may play an important role in the spread of ISAV (Munro et al. 2003). Large-scale spread has been associated with movement of live fish and contaminated equipment between fish farms. ISAV may be transmitted from site to site, for example by feed boats, as suggested for the outbreak in Canada (McClure et al. 2005), or by well boats carrying fish or ballast water, as observed during the Scottish epidemic (Murray et al. 2002).

Infected fish may be infectious up to 4 wk before showing clinical signs (Vågsholm et al. 1994). Once established on a farm, ISAV spreads slowly from cage to cage for several months, with highly variable mortality rates and clinical features (Hammell \& Dohoo 2005b).

Wild salmonids (Plarre et al. 2005) and other wild fish populations (Nylund et al. 2002) can play important roles as natural reservoirs or carriers of ISAV. In addition, vector-borne transmission of ISAV may occur by sea lice (Caligus sp., Lepeophtheirus sp.) (Nylund et al. 1993) and high levels of sea lice infestation have been suggested with major severity of ISA outbreaks in an expert-opinion based study (Gustafson et al. 2005). Although vertical transmission has been suggested (Nylund et al. 2007), there is little evidence of transmission via gonadal products.

In Chile, the epidemiology of ISAV has been particularly interesting but scarcely documented. The first outbreak was reported in 1997 and limited exclusively to farmed Coho salmon Oncorhynchus kisutch. This new condition was subsequently named icteric (jaundice) syndrome, infectious hemolytic anemia or nonclassical ISA, with a clear spatial (southern Chiloé Island) and temporal (autumn) pattern. Empirical factors related to genetic, nutrition, stressors (grading/ handling) and co-infection with another disease, such as that caused by Piscirickettsia salmonis, were considered more important than the infection caused by the ISAV per se (Smith et al. 2002, 2006). ISAV isolated from diseased Coho salmon was considered rare or atypical in 1999 and genetically related with the North American genogroup (Kibenge et al. 2001). Since then, ISAV has been isolated solely from Coho salmon and official surveillance programs enforced by the Chilean fish health authority (Servicio Nacional de Pesca, Sernapesca) failed to isolate ISAV in Atlantic salmon in Chile until 2007 (Sernapesca 2007).

Since the first reporting of ISAV infection in farmed Atlantic salmon in 2007 (OIE 2007), the virus has been reported in several sea sites in the 10th and 11th regions in southern Chile (OIE 2007, Sernapesca 2008a). The primary outbreak was located in one of the densest and most productive zones of farmed salmon in Chile, where 2 individual sea cages showed a sudden increase in mortalities of about $62 \%$ in less than 1 mo (Godoy et al. 2008). Molecular characterization of the ISAV isolated from diseased salmon at the primary outbreak showed a close kinship to Group 3 of the European genotype (Nylund et al. 2003, Godoy et al. 2008), which suggests a different entity from ISAV previously isolated from Coho salmon.

The aim of this study was to report the epidemiology of the first year of the re-emergence of ISAV in the Chilean salmon industry. Through the use of spatial and spatiotemporal analyses, we identified clustered distributions of cases, applying the concept of commercial compartmentalization, which refers to the identification of salmon farming companies that are epidemiologically linked and that share a common health status (Zepeda et al. 2008). This study provides results to generate research hypotheses and make recommendations for surveillance and control in one of the most productive farmed salmon regions in the world.

\section{MATERIALS AND METHODS}

Study area and salmon farms distribution. In Chile, marine salmon farming (grow-out phase) occurs in about 30 companies for 533 out of 1041 authorized sea sites in the 10th, 11th, and 12th regions with harvests of 72,27 and $1 \%$, respectively (Sernapesca 2008b). Atlantic and Coho salmon, and rainbow trout Oncorhynchus mykiss are the primary salmonid species reared, with a few farms rearing King salmon O. tshawytscha. In 2006, 167 million Atlantic salmon smolts were estimated to be distributed in southern Chile, with a mean grow-out phase of 17 mo and final mean weight at harvest of $4.2 \mathrm{~kg}$ (www. salmonchile.cl). In total, about 375 out of 533 active farms raised salmon in the 10th region (Halwart et al. 2007). For descriptive analyses, we followed the geographic division of the 26 zones into the 10th region established by Sernapesca as part of the official program for management of sea lice (Cali- 
gus sp.) infestations (Sernapesca 2008c). An assumption for all analyses was that all farms in the 10th region held ISAV-susceptible fish during the study period.

Coordinate references of active salmon farms were previously collected by F. O. Mardones for the 10th region. This information was checked and complemented with the Directory of the Chilean aquaculture and fisheries (www.dapel.cl) and the official locations from the Undersecretariat of Fisheries (Subpesca) available online (www.subpesca.cl/carto_acuie3.htm), which contains information for all salmon farms in salt water in Southern Chile. The final dataset contained information for 373 salmon farms distributed within the 10th region of Southern Chile for all salmon species (Fig. 1). Each salmon farm was assigned a unique identification (ID) number and the name and company were codified to maintain confidentiality. Visualization of point locations of all salmon farms in the 10th region was achieved using ArcView GIS Version 9.2 for Windows (ESRI), and projected for analysis using the WGS 1984 datum as a coordinate system.

Surveillance reports of ISAV infected farms. After the first confirmed Chilean case of ISAV in Atlantic salmon (in June 2007), reporting suspected or confirmed farms to the Chilean fish health authority (Sernapesca), was compulsory in Chile. Sernapesca followed the OIE recommendations in the diagnostic manual for aquatic animals to classify a confirmed or suspected farm. Accordingly, a farm was suspected of being infected if it had positive results under official diagnostic tests (virus isolation, reverse transcriptasepolymerase chain reaction (RT-PCR) or immunofluorescent antibody technique). Infection was confirmed if, in addition to a positive test result, a farm had clinical signs and/or post-mortem features attributable to ISA in at least 1 sea cage. Because more than $80 \%$ of the initially suspected farms ultimately became confirmed cases (Sernapesca 2008a) and because of the highly contagious nature of the viral disease, farms where the disease was suspected were assumed to be infected (cases). Sensitivity of the results to this assumption was tested by repeating the tests, considering only confirmed outbreaks as cases and alternatively including suspected farms as controls or excluding them from all analyses.

Reports about each infected farm included date of the report, name of the farm and owning company, official identification number, and control measures established, e.g. preemptive slaughter or harvest in 1 or more cages, or all cages in a farm, and end of the fallowing period. These reports were updated regularly whenever epidemiologic information was included or modified in Sernapesca's webpage (www.serna pesca.cl). These reports were downloaded, compiled, organized, and checked for errors and inconsistencies with a spreadsheet program. Additional information from the first 6 confirmed cases was complemented with immediate notification (ID 5890) of and follow-up reports from the World Animal Health Information Database (WAHID, www.oie.int/wahid) (OIE 2007).

Epidemic analysis. A weekly-based epidemic curve was created based on the number of reported infected cases (confirmed or suspected) after the index case (IC), between June 15, 2007 and August 31, 2008. Additionally, curves were created for the $4 \mathrm{wk}$ period moving average, cumulative incidence of cases, and cumulative number of reported ISAV (+) companies.

Disease confirmation lag (DCL) was estimated as the difference between the dates of first suspicion and the final confirmatory report. Similarly, depopulation delay (DD) was defined as the difference between the earliest report for ISAV (suspected or confirmed date) and $90 \mathrm{~d}$ before the end of the fallowing period, which is the minimum fallowing period for any ISAV-confirmed farm established by the authority.

Descriptive statistics and curves were performed using JMP 7 (SAS Institute).

Spatial analyses. Exploratory analyses for clustering of infected farms were assessed by 2 methods suggested for outbreak investigations (Carpenter 2001), assuming Euclidean (straight line) method as an estimation of distances between farms. First, the CuzickEdwards test (Cuzick \& Edwards 1990) was used to detect any overall, globally clustered distribution at the farm level. This purely spatial method determines the number of $k$ th-order nearest-neighbor (NN) case pairs and compares that to the expected number if the spatial distributions of cases and non-cases (controls) were random. In this study, the first 7 orders of nearestneighbors measurements were examined using 999 Monte Carlo iterations and the ClusterSeer 2 software (TerraSeer). The spatial scan test (Kulldorff \& Nagarwalla 1995), a local cluster test, was used to examine whether infected salmon farms were distributed randomly over space and time. A space-time Poisson model (Kulldorff 1997) was selected to compare the disease rate inside a cylindrical space-time window to the population at risk outside the window. The space-time Poisson model was preferred over the space-time Bernoulli model, which is the approximation used for case-control studies, because the former allow for the control of the heterogeneous spatial distribution of commercial compartments. The window moves over the study region and varies in size from zero to a maximum radius $(r)$ with a temporal window of a maximum of $50 \%$ of the total time period. Large values of $r$ may result in the identification of clusters spanned over an extensive geographical area, which would likely impair the value of results to support the decision-making process. A value of $r=25 \mathrm{~km}$ was 


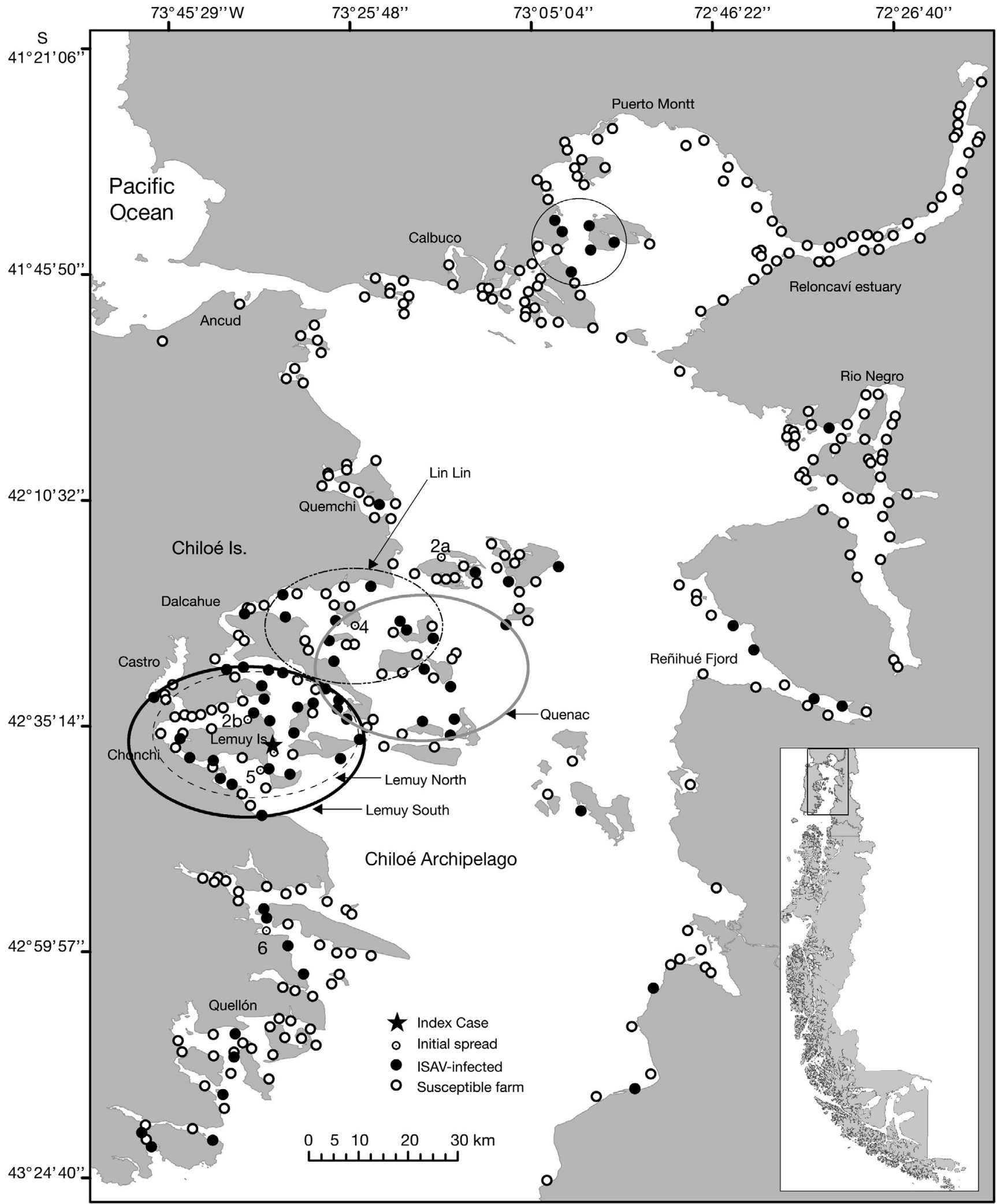

Fig. 1. Distribution of salmon farms in the 10th region of Chile and statistically significant clusters in the space-time analyses (see Table 2). Numbers indicate order of emergence for the first cases during the initial spread. The small circle at the north of the region denotes a group of suspected cases. The ellipsoidal shape of the circles is due to the use of a geographic coordinate system to draw the circles 
used here, which was an approximation for the size of the management geographic zones established by Sernapesca in the 10th region (Sernapesca 2008c). Thus, detected clusters indicate common networks of contacts between farms to environmental, demographic, and managerial conditions, at high risk of ISAV infection. The window was centered on a single farm at a particular time (starting June 15, 2007, first ISAV outbreak) and expanded up to $25 \mathrm{~km}$ to include more farms (cases and controls) for the defined time aggregation length (7 d), after which another farm was selected and the same procedure was followed for all farms in the study. For each window of varying position and size, the software calculated the risk of ISAV infection within and outside the window, with the null hypothesis of equal risk. Monte Carlo replications ( $\mathrm{n}=999$ ) were run to determine the distribution of the likelihood ratio test statistic and the associated pvalue (Kulldorff \& Nagarwalla 1995). Results obtained from the unadjusted or crude space-time Poisson models were compared when the model was adjusted by the commercial compartment variable (company). All analyses were performed using the SaTScan software program (SaTScan version 7.0, www.satscan.org). For all tests, a significance level of $\mathrm{p}<0.05$ was used.

\section{RESULTS}

\section{Epidemic analysis}

Throughout the 64 wk study period of June 15, 2007 to August 31, 2008, 76 of 373 (20.4\%) salmon-raising farms, owned by 17 companies in the 10th region in Chile were reported to have been infected by ISAV (Figs. 1 to 3). Visual inspection of the epidemic and the 4 wk moving average curves showed high variability during the epidemic such as observed for propagated epidemic (Fig. 2). The median epidemic date was determined as Week 43 (quartiles $25 \%=$ Week 26, $75 \%$ = Week 54) (Fig. 3).

During the initial $10 \mathrm{wk}$ period of the epidemic, 6 farms reported clinical signs or mortality consistent with ISA. The interval of time between the confirmation of the IC and the first, subsequent outbreaks was almost 1 mo. For these 6 initial cases, the IC reported the largest susceptible population, cases and deaths (Table 1). Of the first 6 cases, 4 were on farms owned by the same company. The mean shortest seaway distance from the IC to these farms was $39 \mathrm{~km}$ (range: 10

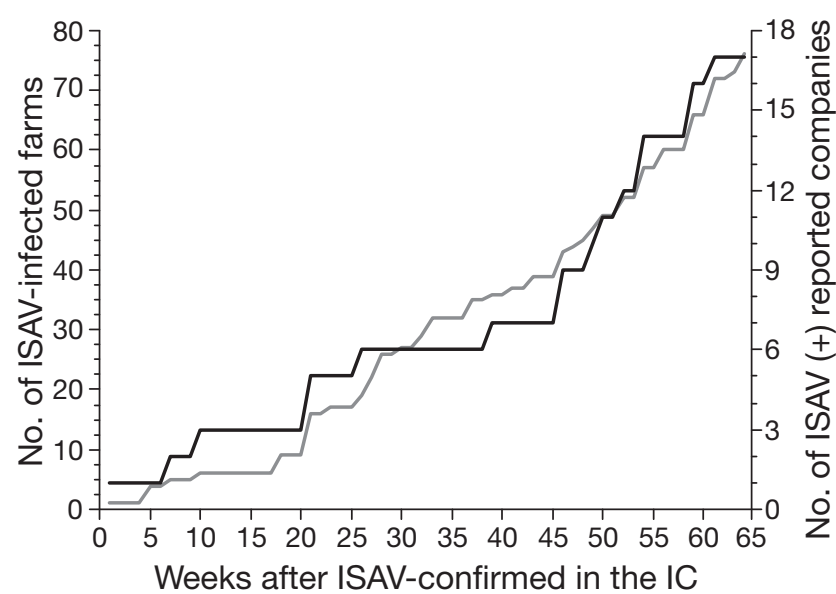

Fig. 3. Cumulative incidence curve of infectious salmon anemia virus (ISAV)-infected salmon farms (grey line) and ISAV (+) reported companies (black line) between June 15, 2007 and August 31, 2008, in the 10th region of Chile

to $65 \mathrm{~km}$ ). After the end of the last reported outbreak in this initial spread (August 17, 2007), no infected farm was reported for the next 2 mo (Fig. 2).

During the following $11 \mathrm{mo}, 70$ infected farms were reported, involving another 13 different companies. The epidemic peak occurred quickly by Week 21, when 7 farms were reported infected (Figs. 2 \& 3).

In the study period, 13 of 76 farms (17\%) were reported immediately as confirmed outbreaks, 48 of 76 $(63 \%)$ were reported initially as suspected but later confirmed as cases, and by the end of the study period, 15 of $76(20 \%)$ remained as suspected. Therefore, 48 of the 61 confirmed outbreaks (79\%) were initially reported as suspected.

The mean, median and modal times for the DCL were 9,5, and 4 wk respectively, ranging from 1 to 51 wk (Fig. 4). This interval length changed on time, 
Table 1. Summary of the first 6 outbreaks of infectious salmon anemia (ISA) in Chile adapted from the follow-up report (ID 5890) from the World Organization for Animal Health (OIE) and reports from Sernapesca during 2007. IC = index case. Estimated starting date based on clinical and laboratory results. Susceptible fish lost $=($ dead + slaughtered $) /$ population at risk. Distance to IC estimated from the shortest route via seawater between farms

\begin{tabular}{|c|c|c|c|c|c|c|c|c|c|c|}
\hline $\begin{array}{l}\text { Estimated } \\
\text { starting } \\
\text { date }\end{array}$ & Company & $\begin{array}{l}\text { Distance } \\
\text { to the IC } \\
(\mathrm{km})\end{array}$ & $\begin{array}{l}\text { Population } \\
\text { at risk } \\
\text { (N) }\end{array}$ & $\begin{array}{c}\text { Dead } \\
(\mathrm{N})\end{array}$ & $\begin{array}{c}\text { Cases } \\
(\mathrm{N})\end{array}$ & $\begin{array}{l}\text { Harvested } \\
\text { (N) }\end{array}$ & $\begin{array}{c}\text { case } \\
\text { morbidity (\%) }\end{array}$ & $\begin{array}{l}\text { - Apparent } \\
\text { case } \\
\text { fatality }(\%)\end{array}$ & $\begin{array}{c}\text { mortality } \\
(\%)\end{array}$ & $\begin{array}{c}\text { Susceptible } \\
\text { fish lost } \\
(\%)\end{array}$ \\
\hline 15 June & A & - & 1933000 & 220000 & 598384 & 1064606 & 31.0 & 36.8 & 11.4 & 66.5 \\
\hline 13 July & A & 65 & 1168655 & 9529 & 43000 & 32497 & 3.7 & 22.2 & 0.8 & 3.6 \\
\hline 13 July & A & 10 & 593206 & 13352 & 173926 & 160574 & 29.3 & 7.7 & 2.3 & 29.3 \\
\hline 19 July & B & 24 & 611622 & 1261 & 258083 & 94387 & 42.2 & 0.5 & 0.2 & 15.6 \\
\hline 30 July & A & 42 & 392052 & 31623 & 60121 & 360429 & 15.3 & 52.6 & 8.1 & 100 \\
\hline 17 August & $\mathrm{C}$ & 53 & 57904 & 16580 & 19506 & 2400 & 33.7 & 85 & 28.6 & 32.8 \\
\hline
\end{tabular}

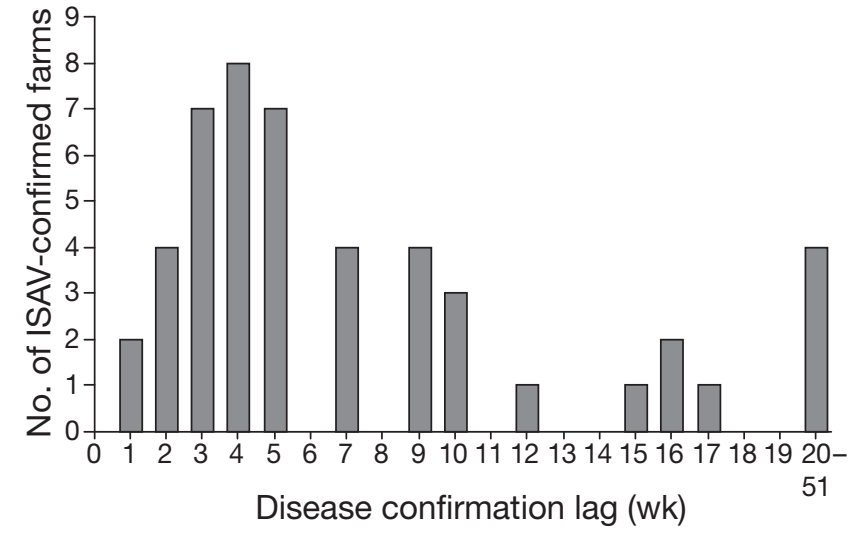

Fig. 4. Frequency distribution for the disease confirmation lag in weeks, during the infectious salmon anemia virus (ISAV) epidemic between June 15, 2007, and August 31, 2008 $($ mean $=9 \mathrm{wk}$, median $=5 \mathrm{wk}$, mode $=4 \mathrm{wk})$, in the $10 \mathrm{th}$ region of Chile

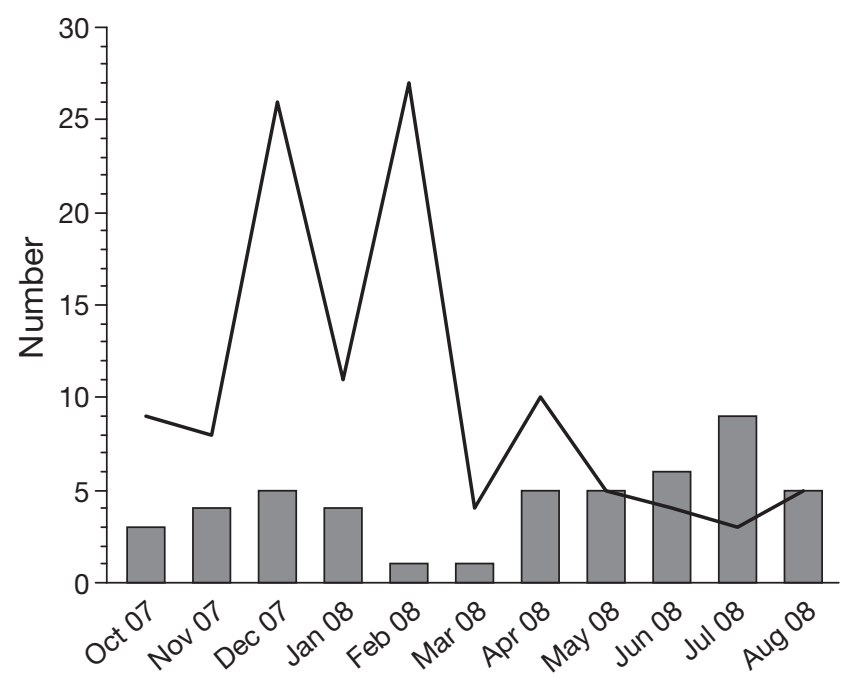

Fig. 5. Average disease confirmation lag in weeks (line) and monthly number of salmon farms becoming confirmed after initial suspicion (bars) during the infectious salmon anemia virus epidemic between June 15, 2007 and August 31, 2008, in the 10th region of Chile and was considerably shorter during the last 4 months of the epidemic (Fig. 5). Most of the suspected farms $(73 \%)$ were reported by the middle of the epidemic (21 to 37 wk, Fig. 2), and 9 of 15 (60\%) were managed by the same company.

Estimation of DD interval was obtainable for 52 ISAV farms. The IC and the first 5 outbreaks showed an estimated DD interval of 4 to 5 mo from the first ISAV detected and cleared farm. This interval was similar during the study period, ranging from 3 to 54 wk (Fig. 6).

\section{Spatial analyses}

ISAV-infected farms were widely distributed along the coast of the 10th region (Fig. 1). Seventeen of the 26 geographic zones in the 10 th region (65\%) reported

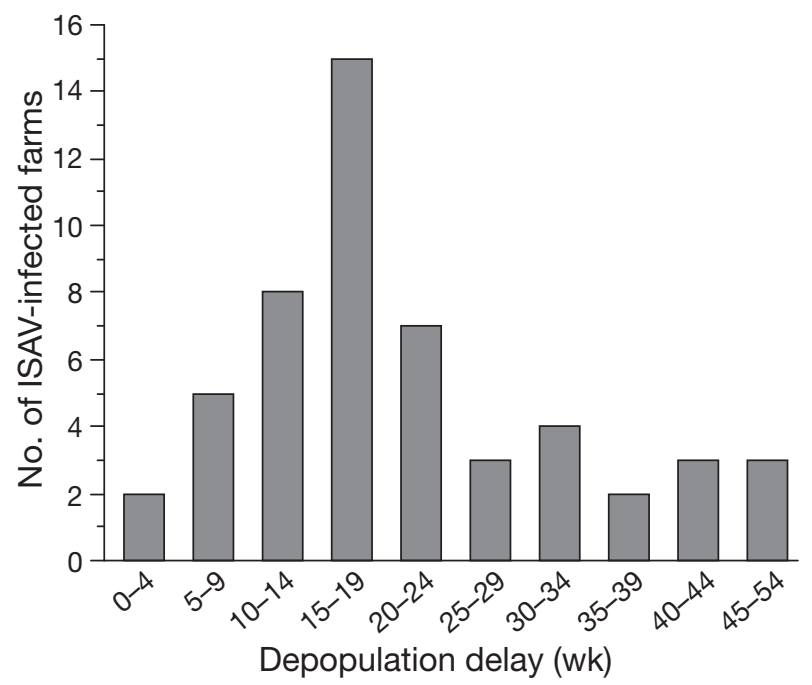

Fig. 6. Frequency distribution of the depopulation delay for 52 infectious salmon anemia virus (ISAV)-infected farms during the ISAV epidemic between June 15, 2007 and August 31, $2008($ mean $=21 \mathrm{wk}$, median $=17 \mathrm{wk}$, mode $=15 \mathrm{wk})$, in the 10th region of Chile 
ISAV-infected farms. ISAV-free zones were predominantly in the northern part of the region.

Results of the Cuzick-Edwards test identified significant overall clustering of infected farms during the epidemic in all 7 th order NNs examined $(p<0.001)$. Results were insensitive to either the inclusion of suspected farms as controls or to their exclusion from the analyses.

The space-time Poisson models identified 4 clusters of farms at high risk of being ISAV-infected (Table 2). When confirmed and suspected farms were considering cases of disease, 2 statistically significant clusters $(p \leq 0.002)$ were identified. The first cluster (Lemuy North) was detected between October 15, 2007 and February 3, 2008. It had a radius of $14.3 \mathrm{~km}$ from an infected farm located in the eastern coast of the Lemuy Island (centered at $42^{\circ} 34^{\prime} 39^{\prime \prime} \mathrm{S}, 73^{\circ} 34^{\prime} 51^{\prime \prime} \mathrm{W}$ ), about $6 \mathrm{~km}$ north of the IC. It included 44 salmon farms, among which 18 were reported cases during the period, approximately 13 times the expected number. Sixteen of the $18(89 \%)$ of the reported infected farms in the spatiotemporal cluster were owned by the same company, which managed the IC. The second cluster (Lin Lin) consisted of 5 infected farms (expected $<1$ ) owned by 3 companies, and 19 non-infected farms next to the first cluster (centered at $42^{\circ} 24^{\prime} 21^{\prime \prime} \mathrm{S}$, $73^{\circ} 25^{\prime} 28^{\prime \prime} \mathrm{W}$, radius $=12.3 \mathrm{~km}$ ) and occurred from August 11 to 17, 2008.

The adjusted space-time Poisson model identified the same secondary cluster as the unadjusted model (Lin Lin), however, adjustment by the company resulted in a primary cluster (Lemuy South, radius $=20.1 \mathrm{~km}$, centered at $42^{\circ} 38^{\prime} 58^{\prime \prime} \mathrm{S}, 73^{\circ} 37^{\prime} 56^{\prime \prime} \mathrm{W}$ ) deviated $10 \mathrm{~km}$ southeast in the same time frame period, and with decreased relative risk from 10 to 7 (30\%) compared to the unadjusted primary cluster (Lemuy North).

Detection of the cluster centered in Lin Lin was not sensitive to changes in the case definition (Table 2).
However, exclusion of suspected farms from the analysis or their inclusion as controls resulted in disappearance of the Lemuy clusters and in the detection of a new cluster centered between April 28 and August 31, 2008 ( $\mathrm{p} \leq 0.001$ ). This cluster (Quenac) was located in the center of the Chiloé archipelago (centered at $42^{\circ} 28^{\prime} 59^{\prime \prime} \mathrm{S}, 73^{\circ} 18^{\prime} 10^{\prime \prime} \mathrm{W}$, radius $=15.6 \mathrm{~km}$ ) and included 13 farms owned by 8 companies, from a total of 29 salmon farms that were at risk (expected $<2$ ). The relative risk for a salmon farm in this cluster was 12 . These results suggest that clusters centered in Lemuy and Quenac were sensitive to the case definition used here.

\section{DISCUSSION}

We have presented an insight into the epidemiology of the re-emergence of ISAV in salmon farming which resulted from the analysis of surveillance reports during an epidemic in Chile. As expected for a highly transmissible disease, ISAV spread quickly over a large area and cases were spatially and temporally clustered, infecting farms owned by one-half of the salmon companies in the Chilean industry. Since the time when the analyses presented here were performed, the number of confirmed and suspected cases increased to, respectively, 30 and 12 in the study region, and to 20 and 44 throughout Chile, including the spread of the disease from the 10th to the 11th and 12 th regions.

The IC was situated in the most productive salmon farming area in Chile. Distances of initial subsequent outbreaks to the IC (see Fig. 1) suggested that, at the beginning of the epidemic, ISAV transmission, other than water-borne or proximal, resulted in a highly dispersed pattern of spread. This observation resembled

Table 2. Statistically significant clusters $(\mathrm{p}<0.01)$ detected by a retrospective Poisson model using the space-time scan statistic for the ISAV epidemic between June 15, 2007, and August 31, 2008, in the 10th region of Chile. RR: relative risk; Obs.: observed; Exp.: expected

\begin{tabular}{|c|c|c|c|c|c|c|c|c|c|c|}
\hline \multirow[t]{2}{*}{$\begin{array}{l}\text { Models (cases/ } \\
\text { population at risk) }\end{array}$} & \multirow[t]{2}{*}{ Adjusted } & \multirow[t]{2}{*}{$\begin{array}{l}\text { Type of } \\
\text { cluster }\end{array}$} & \multirow[t]{2}{*}{$\mathrm{RR}$} & \multirow[t]{2}{*}{$\begin{array}{l}\text { Cluster } \\
\text { center }\end{array}$} & \multirow[t]{2}{*}{$\begin{array}{l}\text { Radius } \\
(\mathrm{km})\end{array}$} & \multirow[t]{2}{*}{$\begin{array}{l}\text { Cluster } \\
\text { period }\end{array}$} & \multirow[t]{2}{*}{$\begin{array}{l}\text { No. of } \\
\text { farms }\end{array}$} & \multicolumn{2}{|c|}{$\begin{array}{l}\text { No. of } \\
\text { cases }\end{array}$} & \multirow[t]{2}{*}{$\mathrm{p}$} \\
\hline & & & & & & & & Obs. & Exp. & \\
\hline \multirow{4}{*}{$\begin{array}{l}\text { Confirmed and } \\
\text { suspected } \\
(76 / 373)\end{array}$} & No & Primary & 10 & Lemuy North & 14.3 & 15 Oct $07-3$ Feb 08 & 44 & 18 & $<3$ & 0.001 \\
\hline & Yes & & 7 & Lemuy South & 20.1 & & 53 & 19 & $<4$ & 0.001 \\
\hline & No & Secondary & 69 & Lin Lin & 12.3 & 11-18 Aug 08 & 24 & 5 & $<1$ & 0.002 \\
\hline & Yes & & 58 & & & & & & & 0.004 \\
\hline \multirow[t]{2}{*}{$\begin{array}{l}\text { Only confirmed } \\
(61 / 373)\end{array}$} & No & Primary & 12 & Quenac & 15.6 & 28 Apr-31 Aug 08 & 29 & 13 & $<2$ & 0.001 \\
\hline & Yes & Primary & 79 & Lin Lin & 12.3 & 11-18 Aug 08 & 24 & 5 & $<1$ & 0.002 \\
\hline \multirow{2}{*}{$\begin{array}{l}\text { Only confirmed, } \\
\text { suspected excluded } \\
(61 / 358)\end{array}$} & No & Primary & 12 & Quenac & 15.6 & 28 Apr-31 Aug 08 & 28 & 13 & $<2$ & 0.001 \\
\hline & Yes & Primary & 73 & Lin Lin & 12.3 & 11-18 Aug 08 & 23 & 5 & $<1$ & 0.002 \\
\hline
\end{tabular}


the initial broad pattern of spread during the ISAV epidemic in Scotland in 1998 (Stagg 2003) in which anthropogenic activities such as movement of live or harvested fish or their byproducts were suspected to have played a more important role than environmental or passive transmission (Murray et al. 2002).

As in the Scottish epidemic (Stagg et al. 2001), the IC in the Chilean epidemic was densely populated with approximately 2 million salmon, approximately double the size (750000 to 1200000 salmon) of a traditional salmon farm in Chile (Halwart et al. 2007). The large proportion of salmon reported to be infected (apparent morbidity $=31 \%$ ) suggested a significant proportion of infected fish was capable of spreading the virus (Table 1).

Although geographical and commercial/industrial characteristics are different in both regions, the attack rate estimated for the equivalent period in Scotland (31 ISAV infected farms out of 343 active sites, $9 \%$ ) (Murray 2003) was considerably smaller than in the Chilean epidemic $(20 \%)$.

During the Scottish epidemic, it is believed that timely depopulation played a key role in the successful eradication efforts. In fact, the IC was cleared within the first month, compared with an estimated 4 to 5 mo in the Chilean epidemic. Furthermore, the mean depopulation delay of subsequent infected farms was about 3 wk in the Scottish epidemic (Stagg et al. 2001, Stagg 2003) compared with 16 wk in the Chilean epidemic. Observations of ISA events in North America showed that early removal of infected cages effectively limits ISAV spread (Gustafson et al. 2006) and timely depopulation has been important in the control of other highly infectious diseases such as FMD or AI (Howard \& Donnelly 2000). Although detailed information to estimate depopulation delays was not available for all ISAV-infected farms in Chile, we believe delayed depopulation may have played an important role in the subsequent spread of ISAV.

The re-emergence of ISAV in Chile is responsible for one of the largest epidemics, surpassed only between 1989 and 1991, when 215 farms reported ISA outbreaks in Norway (Lyngstad et al. 2008). As in previous ISA epidemics, cases were clustered around the IC, which supports the hypothesis that passive transmission in seawater through normal discharge from ISAVinfected farms (proximity) is the most important risk factor in the spread of the disease, as suggested elsewhere (Vågsholm et al. 1994, Jarp \& Karlsen 1997, Gustafson et al. 2005, McClure et al. 2005).

The occurrence of the primary cluster, Lemuy South, was associated with the commercial compartment evaluated, where $89 \%$ of infected cases were owned by the same company, which managed the IC and 3 of the 5 initial ISAV outbreaks. After controlling for the variable as potential confounder in the space-time Poisson model, the relative risk in the cluster was reduced substantially (16 to $30 \%$ ) in all clusters, suggesting that company explained some of the excess in the number of outbreaks within the clusters (Lemuy North and South, and Lin Lin). This highlights the importance of compartmentalization (Zepeda et al. 2008) in addition to geographic management areas (zoning), when controlling infectious diseases strategies within a region. The clusters detected in Lemuy and Quenac were sensitive to the assumption of considering suspected farms as cases of the disease. Interestingly, detection of the cluster centered in Quenac resulted in disappearance of the cluster centered in Lemuy and vice versa, and this difference was associated with the use of alternative case definitions. Because of the long DCL of the disease (Fig. 4) and because at the time when analyses were performed the infection was still spreading in the region, it is possible that at least some of the suspected farms were still to be confirmed. Alternatively, because one would expect that farms close to confirmed cases would be more closely inspected than far-away farms, a high proportion of suspected farms in the Lemuy cluster may simply be the reflection of high intensity of surveillance. Additionally, because estimates of the test specificity were not available to us, it is possible that infection was suspected in some of the farms as a consequence of false-positive test reactions. In any case, suspected farms included within the cluster centered in Lemuy, which was detected when suspected farms were considered cases, should be further assessed in order to estimate the true risk status of the region.

Potential pitfalls of this study are related to the limited information obtainable from surveillance reports, especially associated with demographic characteristics of farms (e.g. species, population at risk, biomass), primary detection method for ISAV, and specific dates of exposure/infection. Although farmed Coho Salmon and rainbow trout are susceptible to ISAV, and the productive cycle of these species in sea water can be at least $1 \mathrm{yr}$, this study assumed homogeneity of salmon farms to susceptibility and stocking history. This farmlevel information (e.g. species, biomass, year-class, type of farm, etc.) is difficult to obtain and rarely available, as similarly experienced during the Canadian epidemic (Gustafson et al. 2005). Moreover, this study did not explore the hypothesized role of multiple ISAV genotypes in the epidemic, as data were not available.

It is noteworthy that the emergence of a cluster of suspected farms at the north of the 10th region (Fig. 1) may emphasize the importance of these farms in the epidemiology and control of ISA. In this group, the first suspected case was reported in the middle of December 2007 (Week 26). Five subsequent suspected cases 
were reported in a period of $6 \mathrm{mo}$, but only one of them was reported as confirmed, i.e. developed clinical signs, after 4 mo (Fig. 5).

In this preliminary study, techniques for the detection of spatial and spatiotemporal clusters during outbreak investigations (Carpenter 2001) were shown to be applicable for aquaculture activities. Future studies need to approach the potential role of network connections, for example, exploring the closest shoreline distances between farms, which may or may not differ from the Euclidean distances as presented here. Additionally, the spatiotemporal method used here has the limitation of detecting clusters in a defined cylindrical or ellipsoidal window, including potential bias as the distribution of salmon farms follows a shoreline or linear arrangement. Although methods for the detection of flexible clusters have been described elsewhere (Takahashi et al. 2008), software to apply such methods to detection of time-space clusters are yet to be developed.

In this investigation, ISAV re-emerged as a propagated epidemic and cases were clustered in the middle of the Chiloé archipelago, where risk of an outbreak was significantly higher than for the rest of the 10th region. Future research may focus attention on attributes for ISAV transmission that might be more prevalent in the detected clusters.

Acknowledgements. The authors are grateful to Dr. R. Hedrick, UC Davis, for his expertise and cooperation in this study. We also thank the numerous industry representatives who assisted in this study.

\section{LITERATURE CITED}

Anonymous (2002) Salmon virus detected in Clew Bay fish farm. The Irish Times, Dublin, www.irishtimes.com/ newspaper/ireland/2002/0812/1027742409320.html

Carpenter TE (2001) Methods to investigate spatial and temporal clustering in veterinary epidemiology. Prev Vet Med 48:303-320

Cuzick J, Edwards R (1990) Spatial clustering for inhomogeneous populations. J R Stat Soc Ser B Stat Methodol 52: 73-104

Falk K, Namork E, Rimstad E, Mjaaland S, Dannevig BH (1997) Characterization of infectious salmon anemia virus, an orthomyxo-like virus isolated from Atlantic salmon (Salmo salar L.). J Virol 71:9016-9023

Godoy MG, Aedo A, Kibenge MJ, Groman DB and others (2008) First detection, isolation and molecular characterization of infectious salmon anaemia virus associated with clinical disease in farmed Atlantic salmon (Salmo salar) in Chile. BMC Vet Res 4:28

Gustafson LL, Ellis SK, Bartlett CA (2005) Using expert opinion to identify risk factors important to infectious salmonanemia (ISA) outbreaks on salmon farms in Maine, USA, and New Brunswick, Canada. Prev Vet Med 70:17-28

Gustafson L, Ellis S, Hawkins L, Moore M, Robinson T, MacPhee D (2006) A preliminary investigation of the rela- tionship between infected cage removal speed and resultant spread of infectious salmon anemia on Atlantic salmon farms in Maine, USA and New Brunswick, Canada. In: Scarfe AD, Lee CS, O'Bryen PJ (eds) Biosecurity in aquaculture production systems: prevention, control, and eradication of aquatic animal disease. Blackwell Publishing, Aimes, IA, p 165-172

Gustafson L, Ellis S, Robinson T, Marenghi F and others (2007) Spatial and non-spatial risk factors associated with cage-level distribution of infectious salmon anaemia at three Atlantic salmon, Salmo salar L., farms in Maine, USA. J Fish Dis 30:101-109

Halwart M, Soto D, Arthur JR (2007) Cage aquaculture: regional reviews and global overview FAO Fish Tech Pap No. 498. Food and Agriculture Organization of the United Nations (FAO), Rome

Hammell KL, Dohoo IR (2005a) Risk factors associated with mortalities attributed to infectious salmon anaemia virus in New Brunswick, Canada. J Fish Dis 28:651-661

Hammell KL, Dohoo IR (2005b) Mortality patterns in infectious salmon anaemia virus outbreaks in New Brunswick, Canada. J Fish Dis 28:639-650

> Howard SC, Donnelly CA (2000) The importance of immediate destruction in epidemics of foot and mouth disease. Res Vet Sci 69:189-196

Jarp J, Karlsen E (1997) Infectious salmon anaemia (ISA) risk factors in sea-cultured Atlantic salmon Salmo salar. Dis Aquat Org 28:79-86

Kibenge FSB, Gárate ON, Johnson G, Arriagada R, Kibenge MJT, Wadowska D (2001) Isolation and identification of infectious salmon anaemia virus (ISAV) from Coho salmon in Chile. Dis Aquat Org 45:9-18

Kulldorff M (1997) A spatial scan statistic. Commun Stat Theor Meth 26:1481-1496

Kulldorff M, Nagarwalla N (1995) Spatial disease clusters: detection and inference. Stat Med 14:799-810

Lovely JE, Dannevig BH, Falk K, Hutchin L and others (1999) First identification of infectious salmon anaemia virus in North America with haemorrhagic kidney syndrome. Dis Aquat Org 35:145-148

Lyngøy C (2003) Infectious salmon anemia in Norway and the Faroe Islands: an industrial approach. In: Miller O, Cipriano RC (tech coords) International response to infectious salmon anemia: prevention, control, and eradication. USDA, Animal Plant Health Inspect Serv, US Dept Interior, USGS, US Dept Commerc, Natl Mar Fish Serv, Washington, DC, p 97-109

Lyngstad TM, Jansen PA, Sindre H, Jonassen CM, Hjortaas MJ, Johnsen S, Brun E (2008) Epidemiological investigation of infectious salmon anaemia (ISA) outbreaks in Norway 2003-2005. Prev Vet Med 84:213-227

> McClure CA, Hammell KL, Dohoo IR (2005) Risk factors for outbreaks of infectious salmon anemia in farmed Atlantic salmon, Salmo salar. Prev Vet Med 72:263-280

Mullins JE, Groman D, Wadowska D (1998) Infectious salmon anaemia in salt water Atlantic salmon (Salmo salar L.) in New Brunswick, Canada. Bull Eur Assoc Fish Pathol 18: 110-114

Munro PD, Murray AG, Fraser DI, Peeler EJ (2003) An evaluation of the relative risks of infectious salmon anaemia transmission associated with different salmon harvesting methods in Scotland. Ocean Coast Manag 46:157-174

Murray AG (2003) The epidemiology of infectious salmon anemia in Scotland. In: Miller O, Cipriano RC (tech coords) International response to infectious salmon anemia: prevention, control, and eradication. USDA, Animal Plant Health Inspect Serv, US Dept Interior, USGS, US 
Dept Commerce, Natl Mar Fish Serv, Washington, DC, p 55-62

Murray AG, Smith RJ, Stagg RM (2002) Shipping and the spread of infectious salmon anemia in Scottish aquaculture. Emerg Infect Dis 8:1-5

Nylund A, Wallace C, Hovland T (1993) The possible role of Lepeophtheirus salmonis (Kroyer) in the transmission of infectious salmon anemia. In: Boxshall GA, Defaye D (eds) Pathogens of wild and farmed fish: sea lice. Ellis Horwood Limited, Chichester, p 367-373

Nylund A, Devold M, Mullins J, Plarre H (2002) Herring (Clupea harengus): a host for infectious salmon anemia virus (ISAV). Bull Eur Assoc Fish Pathol 22:311-318

- Nylund A, Devold M, Plarre H, Isdal E, Aarseth M (2003) Emergence and maintenance of infectious salmon anaemia virus (ISAV) in Europe: a new hypothesis. Dis Aquat Org 56:11-24

Nylund A, Plarre H, Karlsen M, Fridell F, Ottem KF, Bratland A, Saether PA (2007) Transmission of infectious salmon anaemia virus (ISAV) in farmed populations of Atlantic salmon (Salmo salar). Arch Virol 152:151-179

OIE (2007) Immediate notification report No 5890, Infectious salmon anaemia, Chile. Office International des Epizooties, Paris

Perez AM, Ward MP, Carpenter TE (2004) Epidemiological investigations of the 2001 foot-and-mouth disease outbreak in Argentina. Vet Rec 154:777-782

Plarre H, Devold M, Snow M, Nylund A (2005) Prevalence of infectious salmon anaemia virus (ISAV) in wild salmonids in western Norway. Dis Aquat Org 66:71-79

Rodger HD, Turnbull T, Muir F, Millar S, Richards RH (1998) Infectious salmon anaemia (ISA) in the United Kingdom. Bull Eur Assoc Fish Pathol 18:115-116

Sernapesca (2007) Informe sanitario de la acuicultura nacional, 2006. Servicio Nacional de Pesca (Sernapesca), Valparaíso

Sernapesca (2008a) Balance de la situación sanitaria de la anemia infecciosa del salmón en Chile, Julio 2007-2008. Servicio Nacional de Pesca (Sernapesca), Valparaíso

Sernapesca (2008b) Cifras preliminares de desembarque, cosechas y agentes pesqueros y de acuicultura, 2007. Ser-

Editorial responsibility: Julie Bebak, Auburn, Alabama, USA vicio Nacional de Pesca (Sernapesca), Valparaíso

Sernapesca (2008c) Informe No 1: Programa de vigilancia y control de caligidosis. Servicio Nacional de Pesca (Sernapesca), Valparaíso

Smith PA, Larenas J, Contreras J, Cassigoli J and others (2002) Infectious haemolytic anaemia of salmon: an emerging disease occurring in seawater coho salmon (Oncorhynchus kisutch) in Chile. In: Harrington KS (ed) Proc 4th Int Symp Aquat Animal Health, Louisiana Sea Grant College Program, New Orleans, LA

Smith PA, Larenas J, Contreras J, Cassigoli J and others (2006) Infectious haemolytic anaemia causes jaundice outbreaks in seawater-cultured coho salmon, Oncorhynchus kisutch (Walbaum), in Chile. J Fish Dis 29: 709-715

Stagg RM (2003) The eradication of an outbreak of clinical infectious salmon anemia from Scotland. In: Miller $\mathrm{O}$, Cipriano RC (tech coords) International response to infectious salmon anemia: prevention, control, and eradication. USDA, Animal Plant Health Inspect Serv, US Dept Interior, USGS, US Dept Commerce, Natl Mar Fish Serv, Washington, DC, p 111-124

Stagg RM, Bruno DW, Cunningham CO, Raynard RS and others (2001) Epizootiological investigations into an outbreak of infectious salmon anemia (ISA) in Scotland. FRS, Marine Laboratory, Report No 13/01, Aberdeen

Takahashi K, Kulldorff M, Tango T, Yih K (2008) A flexibly shaped space-time scan statistic for disease outbreak detection and monitoring. Int J Health Geogr 7:14

Thorud K, Djupvik HO (1988) Infectious anaemia in Atlantic salmon (Salmo salar L.). Bull Eur Assoc Fish Pathol 8: 109-111

> Vågsholm I, Djupvik HO, Willumsen FV, Tveit AM, Tangen K (1994) Infectious salmon anaemia (ISA) epidemiology in Norway. Prev Vet Med 19:277-290

Ward MP, Maftei D, Apostu C, Suru A (2008) Geostatistical visualisation and spatial statistics for evaluation of the dispersion of epidemic highly pathogenic avian influenza subtype H5N1. Vet Res 39:1-22

> Zepeda C, Jones JB, Zagmutt FJ (2008) Compartmentalisation in aquaculture production systems. Rev Sci Tech 27: $229-241$

Submitted: October 27, 2008; Accepted: January 28, 2009 Proofs received from author(s): April 1, 2009 